\title{
A RECONCILIATION OF HENRY AND WILSON: THE INTERSECTION OF CONSTITUTIONAL RIGHTS WITH PROCEDURAL REVIEW
}

\author{
An open foe may prove a curse, \\ But a pretended friend is worse. \\ John Gay ${ }^{1}$
}

A recent Supreme Court decision, Kuhlmann v. Wilson, ${ }^{2}$ leaves uncertain the state of the law regarding the government's use of jailhouse informants. It is difficult to determine the standards of permissible government behavior by analyzing Wilson against the background of estabhished case law. At first glance, Wilson appears to overrule the preceding sixth amendment cases.

Three cases are integral to understanding the sixth amendment's prohibition of government interrogation in the absence of counsel. The landmark case of Massiah v. United States, ${ }^{3}$ which was decided in 1964, concerned evidence obtained when a co-defendant allowed the government to install a listening device in his car to monitor his post mdictment conversations with Massiah. The Supreme Court held that this procedure constituted government interrogation which violated Massiah's sixth amendment right to counsel ${ }^{4}$ because the government "deliberately

1. Quoted in Spano v. New York, 360 U.S. 315, 323 (1959) (condemning police employment of defendant's childhood friend to manipulate defendant during interrogation).

2. 106 S. Ct. 2616 (1986). See generally Note, Kuhlmann v. Wilson: The Sixth Amendment Right to Counsel: Government Circumvention Through Surreptitious Interrogation, 20 J. MARSHALL L. REV. 567 (1987).

3. 377.U.S. 201, 202-03 (1964).

4. Id. at 206. The Court began expanding the sixth amendment right to counsel in Powell v. Alabama, 287 U.S. 45 (1932), which held that a criminal defendant in a capital case who was unable to present an adequate defense was entitled to the assistance of counsel. Id. at 74. Following Powell, the Supreme Court initially rejected the notion of an absolute right to counsel during police interrogation: Crooker v. California, 357 U.S. 433, $439-41$ (1958) (due process violated only if criminal defendant is so prejudiced by lack of counsel that basic fairness is denied). The Court reversed its position and recognized the defendant's right to counsel in Spano v. New York, 360 U.S. 315 (1959). In Spano, the Court held that a confession obtained through police interrogation was involuntary, violating due process requirements, if the police denied the defendant's reasonable requests to contact an attorney. Id. at 323-24. The right to counsel at postindictment interrogations was solidified by Gideon v. Wainwright, 372 U.S. 335 (1963) (indigent defendant entitled to appointed counsel in noncapital cases), White v. Maryland, 373 U.S. 59 (1963) (lack of counsel when defendant pled guilty at preliminary hearing violated due process rights), and Haynes v. Washington, 373 U.S. 503, 507, 513-15 (1963) (involuntary detention without assistance of counsel during coercive police questioning violated due process). Massiah was decided against this backdrop. 
elicited [incriminating statements] from him after he had been indicted and in the absence of his counsel."s

In 1977, in Brewer v. Williams, ${ }^{6}$ the Court revitalized and expanded Massiah. In Williams, the police had agreed with defense counsel not to question Williams while transporting him following his arraignment on a murder charge. During the trip, an officer told Williams that it would be necessary to find the body as soon as possible to ensure the victim a christian burial. This induced Wilhams to direct the police to the body. ${ }^{7}$ The Supreme Court held that the police behavior constituted interrogation under the Massiah deliberate elicitation standard, and the evidence should have been suppressed. ${ }^{8}$

Finally, in United States v. Henry, ${ }^{9}$ which the Court decided in 1980, Henry's cellinate had agreed to act as an agent for the government, listening for Henry to incriminate himself. The agent successfully obtained incriminating information from Henry and testified against him at trial. The Court found deliberate elicitation under Massiah and Williams and held the evidence inadmissible. ${ }^{10}$

Wilson presented the Court with a fact situation virtually identical to that of Henry, ${ }^{11}$ yet the Court reached the opposite conclusion. The Supreme Court reversed the court of appeals' determination that Henry and Wilson were factually indistinguishable and held that the court of appeals' finding of deliberate elicitation failed to pay proper deference to the state court findings of fact, which precluded identification of a constitutional violation. ${ }^{12}$

This note first examines Henry and Wilson and argues that the cases are factually indistinguishable. ${ }^{13}$ It then shows that the Supreine Court's application of the habeas statute ${ }^{14}$ created the seeiningly inconsistent results. In Henry, the Court dealt directly with the sixth amendment issues

A few weeks after it decided Massiah, the Court, in Escobedo v. Illinois, 378 U.S. 478, 484-85 (1964), reversed a conviction obtained through an impermissible confession and affirmed allegiance to Massiah. The Court held that a law enforcement system that depends on confession "will, in the long run, be less reliable and more subject to abuses than a system which depends on extrinsic evidence independently secured through skillful investigation." Id. at 489 (citations omitted).

5. 377 U.S. at 206.

6. 430 U.S. 387 (1977).

7. Id. at $392-93$.

8. Id. at 399-400. The Court held that the right to counsel attaches not only after indictment but also as soon as adversarial judicial proceedings are initiated. Id. at 401 .

9. 447 U.S. 264 (1980).

10. Id. at 273-75.

11. See infra notes $57-69$ and accompanying text.

12. $106 \mathrm{~S}$. Ct. at 2630.

13. See infra notes $57-69$ and accompanying text.

14. 28 U.S.C. $\$ 2254$ (1982). 
raised by the use of jailhouse informants, while in Wilson, the Court found that its decision was compelled by the statutory requirement that federal courts respect state courts' factual findings. ${ }^{15}$ The note then surveys the legislative history of the habeas statute ${ }^{16}$ and notes the confusion created by the Court's attempts to distinguish factual from legal findings. ${ }^{17}$ The note suggests that the Court's desire to impose finality on habeas litigation and punish the "actually guilty" affected its treatment of Wilson. ${ }^{18}$ Finally, the note argues that the approach taken in Wilson gives inadequate consideration to federal supremacy and to the rights of individual defendants. ${ }^{19}$

\section{THE FACTS OF HENRY AND WILSON}

\section{A. United States v. Henry.}

In United States v. Henry, ${ }^{20}$ the Court addressed the problem of the jailhouse informant for the first time. Henry was arrested and indicted after evidence was found linking him to a bank robbery. Shortly after he was incarcerated, government agents contacted Nichols, a prisoner who had previously acted as a paid informant for the FBI. Nichols told the agent that he was housed in the same cellblock as Henry. The agent instructed Nichols to be alert to any statements made by Henry but not to initiate any conversations or ask any questions. Nichols later contacted the FBI and informed them that he and Henry had engaged in conversations and that Henry had told him about the bank robbery. Nichols was paid for this information. Nichols' testimony was used at Henry's federal district court trial, and Henry was convicted. ${ }^{21}$

Henry sought a writ of habeas corpus under the habeas statute for federal prisoners. ${ }^{22}$ Henry argued at an evidentiary hearing that the government's behavior constituted interrogation under Massiah, during which he had been entitled to have counsel present. ${ }^{23}$ The district court,

\footnotetext{
15. See infra notes 70-78 and accompanying text.

16. See infra notes 79-84 and accompanying text.

17. See infra notes $85-98$ and accompanying text.

18. See infra notes 99-104 and accompanying text.

19. See infra notes $105-112$ and accompanying text.

20. 447 U.S. 264 (1980).

21. Id. at $265-67$.

22. Henry v. United States, 551 F.2d 306 (4th Cir. 1977). The habeas statute provides: A prisoner in custody under sentence of a court established by Act of Congress claiming the right to be released upon the ground that the sentence was imposed in violation of the Constitution or laws of the United States, or that the court was without jurisdiction to impose such sentence, or that the sentence was in excess of the maximum authorized by law, or is otherwise subject to collateral attack, may move the court which imposed the sentence to vacate, set aside or correct the sentence.
}

28 U.S.C. § 2255 (1982).

23. 447 U.S. at 267-68. 
however, found that Henry's constitutional rights had not been violated because the agent, Nichols, had been instructed not to question Henry or seek information from him. ${ }^{24}$

The Supreme Court, affirming the decision of the court of appeals, ${ }^{25}$ held that Henry's sixth amendment right had been violated because deliberate elicitation had occurred. ${ }^{26}$ The Court found three factors crucial in determining that the government's behavior constituted deliberate elicitation under Massiah. ${ }^{27}$ First, Nichols was to be paid only if he produced useful information. Thus, the government provided an attractive incentive for Nichols to obtain a confession. ${ }^{28}$ Second, Nichols was a fellow inmate of Henry. The informant's appearance as a friend and ally could lead a defendant to reveal incriminating information he would never voluntarily reveal to a government agent. Moreover, the FBI was aware that Nichols would easily be able to engage Henry in conversation without arousing his suspicion. ${ }^{29}$ Third, Henry was in custody and under indictment at the time he engaged in conversation with Nichols. The Court observed that powerful psychological forces encourage a defendant to seek aid while he is incarcerated: "[C]onfinement may bring into play subtle influences that will make him particularly susceptible to the ploys of undercover Government agents."30

The Supreme Court accepted the court of appeals' conclusion that Nichols had "deliberately" used his position to obtain information from Henry and that Nichols' conduct was attributable to the government. The intentions of the FBI agent were irrelevant: even accepting the fact that the agent did not intend for Nichols to take affirmative steps to secure information, "he must have known that such propinquity likely would lead to that result." 31 Finally, the Court determined that Nichols was not a passive listener because he had engaged in conversations with Henry and the incriminating statements were the product of these con-

24. Henry v. United States, 590 F.2d 544, 547 (4th Cir. 1978), affd, 447 U.S. 264 (1980) (describing holding of district court); id. at 547 (Butzner, J., concurring) (same). The district court also found that any constitutional violation would have constituted harmless error because other evidence linked Henry to the crime. $I d$. at 547.

25. The court of appeals found that deliberate elicitation had occurred, even if there was no direct questioning, because "association" or "general conversation" could constitute "interrogation." Id. The court of appeals also rejected the district court's holding that any violation would have been harmless error. Id.

26. 447 U.S. at 274.

27. Id. at 270.

28. Id. at 270-71.

29. Id. at 274 n.12.

30. Id.

31. Id, at 271. 
versations. ${ }^{32}$ The Court distinguished and reserved consideration of situations involving an electronic "listening post" or "the situation where an informant is placed in close proximity but makes no effort to stimulate conversations about the crime charged." 33 Thus, the Court held that by placing Henry in a cell with a paid government informant, with the logical result that the informant's presence would induce the defendant to incriminate himself, the government had violated Henry's sixth amendment right to counsel. ${ }^{34}$

\section{B. Kuhlmann v. Wilson. ${ }^{35}$}

Joseph Allan Wilson was arrested for the armed robbery of the Star Taxicab Garage and murder of its dispatcher. Eyewitnesses identified Wilson as having been present on the premises of the garage. Following his arraignment, he was placed in a cell that overlooked the Star Taxicab Garage. Benny Lee, his cellmate, had previously agreed to act as an informant. The police directed Lee to listen to Wilson without asking any questions. Wilson first brought up the crime after looking out the window and saying "Someone's inessing with me." He initially provided Lee with an exculpatory explanation, to which Lee replied that the story "didn't sound too good." Wilson gave Lee varying accounts of the crime over the next few days. Wilson eventually confessed to Lee after Wilson's brother visited him and mentioned that Wilson's family was upset about the murder. Lee related his conversation with Wilson at trial. ${ }^{36}$

Wilson was tried in New York state court in 1972, eight years before the Supreme Court decided Henry. ${ }^{37}$ The trial court found that the informant had followed police instructions not to ask Wilson any questions; Lee had only listened to Wilson's "spontaneous" and "unsolicited" statements. The court thus concluded that the government's conduct did not violate Wilson's constitutional rights and denied Wilson's motion to suppress Lee's testimony. Wilson was later convicted. ${ }^{38}$

32. Id. Under the agent's instructions to Nichols not to ask Henry any questions about the robbery, "Nichols remained free to discharge his task of eliciting the statements in myriad less direct ways." Id. at $271 \mathrm{n} .8$.

33. Id. at $271 \mathrm{n} .9$.

34. Id. at 274. The Court held, "By intentionally creating a situation likely to induce Henry to make incriminating statements without the assistance of counsel, the Government violated Henry's Sixth Amendment right to counsel." Id. The Court noted that the government did not litigate the question of harmless error on appeal. Id. at 275 n.13.

35. 106 S. Ct. 2616 (1986).

36. Id. at 2619-20.

37. Id. at $2620-21$.

38, Id. at 2620 . 
In 1973, Wilson sought a writ of habeas corpus in the United States District Court for the Southern District of New York. In 1978, that court found no interrogation and thus no violation of Wilson's sixth amendment right. ${ }^{39}$ The United States Court of Appeals for the Second Circuit affirmed the trial court's decision. ${ }^{40}$

Wilson again ${ }^{41}$ sought a writ of habeas corpus in 1983, this time asking for retroactive application of Henry. ${ }^{42}$ The district court found that Wilson's statements were "spontaneous," rather than elicited by the government informant. ${ }^{43}$ The court held that the record of the state proceedings "plainly establishe[d]" both that the view of the taxicab garage and a visit from Wilson's brother were the real catalysts of the incriminating statements and that Lee was simply a passive listener. ${ }^{44}$ The district court denied the writ, finding that the state court factual determinations distinguished the case from Henry. ${ }^{45}$

The United States Court of Appeals for the Second Circuit reversed, holding that under the standard of Henry, Lee was not a passive histener, but instead part of a government plan which resulted in the deliberate elicitation of a confession. ${ }^{46}$ The court of appeals focused on Lee's conduct and found that it was indistinguishable from the informant's conduct in Henry. The court explained that "[s]ubtly and slowly, but surely, Lee's ongoing verbal intercourse with Wilson served to exacerbate Wilson's already troubled state of mind." 47 The court held that these circumstances constituted deliberate elicitation under Massiah and Williams. 48

The Supreme Court reversed the court of appeals decision. ${ }^{49}$ It held

39. $I d$

40. Wilson v. Henderson, 584 F.2d 1185, 1192 (2d Cir. 1978), cert. denied, 442 U.S. 945 (1979).

41. Henry was decided by the Supreme Court in 1980. In 1981, Wilson filed a motion in state court to vacate his conviction. That motion was denied by the state trial court, which found both that Henry was factually distinguishable because the informant had been paid and that Henry was not subject to retroactive application. Wilson, $106 \mathrm{~S}$. Ct. at 2621.

42. Wilson v. Henderson, No. 82 Civ. 4397 (S.D.N.Y. Mar. 30, 1983), reprinted in Petition for a Writ of Certiorari app. C, at 24a, Kuhlmann v. Wilson, 106 S. Ct. 2616 (1986) (No. 84-1479).

43. Id., reprinted in Petition for a Writ of Certiorari app. C, at 28a. The district court did not articulate its reason for hearing the second habeas corpus petition.

44. Id.

45. Id., reprinted in Petition for a Writ of Certiorari app. C, at 28a-29a. In light of this conclusion, the court did not reach the issue of whether Henry would be retroactively applicable. Id., reprinted in Petition for a Writ of Certiorari app. C, at 27a n.3.

46. Wilson v. Henderson, 742 F.2d 741, 744-45 (2d Cir. 1984), rev'd, 106 S. Ct. 2616 (1986). The court of appeals found that the "ends of justice" entitled Wilson to a second habeas petition. Id. at 743 (citing Sanders v. United States, 373 U.S. 1, 15 (1963)). The court also found that Henry was to be applied retroactively. Id. at 747 .

47. Id. at 745 .

48. Id.

49. Kuhlmann v. Wilson, 106 S. Ct. 2616, 2631 (1986). 
that because the appellate court's description of the interaction between Lee and Wilson "conflict[ed] with the decision of every other state and federal judge who reviewed this record," the panel had failed to follow the habeas statute's factfinding provision applicable to state prisoners, section 2254(d). ${ }^{50}$ Stating that it was deferring to the state court finding of fact, the Supreme Court found that the government had instructed the informant "only to listen to respondent for the purpose of determining the identities of the other participants in the robbery and murder." 51 The Court found that the case presented the question left open in Henry:52 whether a jailhouse informant may be "placed in close proximity [who] makes no effort to stimulate conversations about the crime charged."53 Such conduct, the Court concluded, is permissible. ${ }^{54}$ To prove a violation of the sixth amendment right to counsel, the defendant must show that the "police and their informant took some action, beyond merely listening, that was designed deliberately to elicit incriminating remarks." 55 The Supreme Court ruled that because the state court findings showed that the agent had followed his instructions, the government had not violated Wilson's sixth amendment right. 56

\section{RECONCILIATION OF HENRY AND WILSON}

\section{A. Wilson and Henry are Not Constitutionally Distinguishable.}

The Supreme Court reached disparate results in Wilson and Henry, although the two cases presented the Court with virtually identical factual situations. The Supreme Court's finding that the two cases are constitutionally distinguishable is problematic. The three factors identified in Henry as critical to establishing deliberate elicitation were also present in Wilson, and the minor factual differences found by the Court do not show that Lee was a passive listener.

Wilson satisfies the three-factor test established in Henry: ${ }^{57}$ Lee was a paid government informant; he lived in the same cellblock with Wilson; and Wilson was under the subtle influences brought about by confinement. Furthermore, the facts in Wilson indicate deliberate elicitation even more clearly than did the facts in Henry. In Henry, the informant

50. Id. Section 2254 (d) is reprinted at text accompanying note 85 .

51. $106 \mathrm{~S}$. Ct. at 2630.

52. Id. at 2628 .

53. Henry, 447 U.S. at 271 n.9; see supra note 33 and accompanying text.

54. Wilson, 106 S. Ct. at 2628.

55. Id. at 2630.

56. Id. at 2630-31.

57. See supra notes 27-30 and accompanying text. 
already shared a cell with the defendant, ${ }^{58}$ while in Wilson, the government placed Wilson in the informant's cell, which overlooked the site of the robbery. ${ }^{59}$ Thus, the government's conduct was more dehiberate and coercive in Wilson than it was in Henry.

The Court held that, based on the state court findings, Lee acted only as a passive listener. ${ }^{60}$ Wilson, however, could not have presented the passive informant "listening post" question left open in Henry. ${ }^{61}$ The factual similarity of the two cases and Lee's lack of passivity preclude this solution. Both informants were instructed to listen to the defendants and not to stimulate conversation about the crimes charged. Although they engaged in conversation with the defendants, both were said to have followed these instructions. ${ }^{62}$ In Henry, the informant's actual words were not dispositive; the totality of the government's behavior established deliberate elicitation. ${ }^{63}$ Wilson and Lee engaged in conversation, just as Henry and Nichols did, and as their relationship developed, Wilson could have been lulled into a false sense of security that led to confession. Clearly, Lee was not passive when he replied to Wilson's first, exculpatory account of the crime that the story "didn't sound too good." 64 Thus, Lee and the police in Wilson were no more passive than Nichols and the police were in Henry.

The Supreme Court, attempting to distinguish Wilson, noted that the agent was employed for the purpose of determining the identities of Wilson's accomplices. The police did not intend for Lee to elicit selfincriminating information because they already had solid evidence of Wilson's guilt. ${ }^{65}$ The Court did not explain the significance of the police officers' intent. ${ }^{66}$ Intent should not be considered a controlling factor in analysis of possible deliberate elicitation. Henry does not require specific intent on the part of the government; it supports a finding of deliberate

58. Henry, 447 U.S. at 266.

59. Wilson, $106 \mathrm{~S}$. Ct. at 2619.

60. Id. at 2630 .

61. Henry, 447 U.S. at 271 n.9.

62. Wilson, 106 S. Ct. at 2630; see Henry, 447 U.S. at 271 . The Henry majority refers to Nichols' behavior in an active light, although there is no explicit finding of active interrogation. See Henry, 447 U.S. at 271 ("[A]ccording to his own testimony, Nichols was not a passive listener; rather he had 'some conversations with Mr. Henry' ...." (quoting Nichols' trial testimony)); id. at 274 ("[I]ncriminating conversations between Henry and Nichols were facilitated by Nichols' conduct ...."). On the other hand, in its brief review of the state court findings, the Wilson Court merely noted that Lee " 'only listened" " to Wilson's " "spontaneous" " and " 'unsolicited' " remarks. $106 \mathrm{~S}$. Ct. at 2630.

63. 447 U.S. at $270-71,274-75$.

64. See $106 \mathrm{~S}$. Ct. at 2630 . Under Henry, any informant who engages in "general conversation" about the crime cannot be considered a passive listener. See Henry, 447 U.S. at 270-71.

65. Wilson, $106 \mathrm{~S}$. Ct. at 2630.

66. See id. at 2630-31. 
elicitation even if the government did not intend to elicit a confession from Wilson where they should have known that such "propinquity likely would lead to that result."67 The Supreme Court deferred to the state court finding that Wilson's statements were "spontaneous' " and " 'unsolicited." "68 But, as the dissent argued, even if Lee's actions were not the immediate cause of Wilson's admission, "the deliberate elicitation standard requires consideration of the entire course of government behavior."69 The acts of placmg Wilson in a cell overlooking the garage and allowing a visit from his brother support a finding of deliberate elicitation, because the police should have known that the result would likely be a confession of guilt.

\section{B. Reconciliation of Wilson and Henry.}

The Supreme Court's disposition of Wilson may cause confusion in the lower courts. Because the cases appear factually indistinguishable, ${ }^{70}$ one might read Wilson to overrule Henry. Courts that accept the Supreme Court's assertion that Henry remains intact ${ }^{71}$ will have diffculty determining the standard for deliberate elicitation. Moreover, law enforcement agencies may be left with inconsistent rules for avoiding constitutional violations. Henry demands that a court assess the totality of the government's behavior, ${ }^{72}$ while Wilson could be read as establishing a more stringent test for deliberate elicitation. ${ }^{73}$

67. Henry, 447 U.S. at 271. See supra note 31 and accompanying text.

68. Wilson, $106 \mathrm{~S}$. Ct. at 2630.

69. Id. at 2639 (Brennan, J., dissenting) ("The State intentionally created a situation in which it was forseeable [sic] that respondent would make incriminating statements without the assistance of counsel ....?").

70. A number of judges have decided that Henry and Wilson are factually indistinguishable. Wilson was convicted before Henry's habeas petition was heard by the Supreme Court. The Fourth Circuit granted Henry's habeas petition shortly after the Second Circuit denied Wilson's first, unsuccessful habeas petition. In his dissent in Henry, Judge Russell of the Fourth Circuit wrote of Wilson: "It is evident that factually this case is on all-fours with our case and that the legal issue is precisely the same." Henry v. United States, 590 F.2d 544, 553 (4th Cir. 1978) (citing Wilson, 584 F.2d 1185, 1191 (2d Cir. 1978)), aff'd, 447 U.S. 264 (1980). In his dissent from the denial of rehearing of Wilson's first habeas petition, Judge Oakes noted that the Fourth Circuit had in Henry "held on the Massiah point directly contrary to the panel majority in this case." 590 F.2d 408, 409 (2d Cir. 1978) (citing Henry v. United States, 590 F.2d 544 (4th Cir. 1978)). The government argued at one point that Wilson and Henry were indistinguishable. See United States v. Sampol, 636 F.2d 621, 637-38 (D.C. Cir. 1980) (noting government position, held prior to Supreme Court decision in Henry, that circumstances of Wilson and Henry were "virtually identical"). Finally, two Supreme Court Justices found sufficient factual similarities between the two cases for Wilson to be governed by Henry. See Wilson, $106 \mathrm{~S}$. Ct. at 2637-39 (Brennan, J., dissenting, joined by Marshall, J.).

71. Wilson, $106 \mathrm{~S}$. Ct. at $2628-30$.

72. Henry, 447 U.S. at $270-71$.

73. One could read Wilson as having limited the deliberate elicitation standards set out in Henry. Because the Court never addressed the three factors that it cited as crucial in Henry, one could read this as a discarding of the test. Deliberate elicitation could then be seen as requiring more 
The Supreme Court's holding in Wilson turned on a procedural issue-the court of appeals' failure to pay due deference to the state court's factual findings. ${ }^{74}$ For the Supreme Court in Wilson, those factual findings precluded identifying a constitutional violation. The Court did not even address the three factors ${ }^{75}$ it had cited as crucial in Henry. The court of appeals' conclusion, according to the Supreme Court, "was based on a fundamental mistake, namely, the Court of Appeals' failure to accord to the state trial court's factual findings the presumption of correctness expressly required by 28 U.S.C. $\$ 2254(d) . " 76$

In Henry, the Court never discussed factfinding; it simply attacked the constitutional issues. ${ }^{77}$ Because Henry involved review of a federal conviction, section 2254(d) did not apply, and the Court was not strictly bound by the trial court's findings of fact.

The most satisfactory reconciliation of Henry and Wilson is to read the first as a case about constitutional protection and the second as a case about factfinding under the federal habeas statute. Under this approach, Henry establishes the standard for finding deliberate elicitation, while Wilson establislies the standard for federal court review of state court convictions. ${ }^{78}$

\section{The Difficulty In Applying Section 2254(D) to INFORMANT CASES}

\section{A. The History and Purposes of Section 2254(d).}

Congress enacted 28 U.S.C. $\$ 2254$ (d) in 1966.79 The chairman of the Committee on Habeas Corpus of the Judicial Conference of the United States, which sponsored tlie legislation, stated that the bill's purpose was "to prevent the abuse of the writ . . . and to expedite the disposition of nonmeritorious and repetitious applications for the writ in

inducement on the part of the informant than merely engaging in general conversation about the crime charged. The Court, however, never said it was dispensing with the reasoning in Henry; rather, as this note argues, the Court directed its energies toward the procedural issues and buried the deliberate elicitation issue in the background.

74. Wilson, $106 \mathrm{~S}$. Ct. at 2630.

75. Henry, 447 U.S. at 270-71.

76. Wilson, $106 \mathrm{~S} . \mathrm{Ct}$. at 2630.

77. See Henry, 447 U.S. at 269-75.

78. If a state court were to find deliberate elicitation under the Henry standard, Wilson would support that conclusion on review. It is only when a federal court is inclined to overturn a state court conviction that Wilson would play a significant role. Thus, the substance of the Henry deliberate elicitation standard remains intact, but federal courts inclined to overturn state court convictions are unable to apply it.

79. Act of Nov. 2, 1966, § 2, Pub. L. No. 89-711, 80 Stat. 1104, 1105. 
Federal courts by State court prisoners." 80 The legislation was intended to lessen the increasing burden that meritless habeas petitions imposed on federal courts ${ }^{81}$ and to encourage state courts to safeguard the constitutional rights of defendants. ${ }^{82}$ The legislation also was intended to minimize the friction between state and federal courts. ${ }^{83}$ The goals of the legislation were to be attained by according a presumption of correctness to factual determinations made at hearings on the merits by state courts. ${ }^{84}$

\section{B. Questions of Law and Fact Under Section 2254(d).}

The application of section 2254(d) is problematic because a federal court must distinguish between issues of fact, issues of law, and mixed questions of fact and law. Section 2254(d) provides:

In any proceeding instituted in a Federal court by an application for a writ of habeas corpus by a person in custody pursuant to the judgment of a State court, a deterinination after a hearing on the merits of a factual issue, made by a State court of competent jurisdiction in a proceeding to which the applicant for the writ and the State or an officer or agent thereof were parties, evidenced by a written finding, written opinion, or other reliable and adequate written indicia, shall be presumed to be correct, unless the applicant shall establish or it shall otherwise appear, or the respondent shall admit $\ldots .{ }^{85}$

80. S. REP. No. 1797, 89th Cong., 2d Sess. 4, reprinted in 1966 U.S. CODE Cong. \& ADMiN. NEws 3663, 3666 (letter from Judge Orie L. Phillips to Sen. Joseph D. Tydings (Sept. 24, 1966)).

81. Id. at 2, reprinted in 1966 U.S. CODE CONG. \& ADMIN. NEwS at 3664.

82. See id. at 3, reprinted in 1966 U.S. CODE CONG. \& ADMIN. NEwS at 3665 (" '[T] $]$ he proposed legislation . . . will be a strong inducement . . . to the State courts in criminal proceedings to safeguard the constitutional rights of defendants.' " (quoting Report of the Committee on Habeas Corpus to the Judicial Conference of the United States)).

83. Sumner v. Mata, 449 U.S. 539, 550 (1981) ("Federal habeas has been a source of friction between state and federal courts, and Congress obviously meant to alleviate some of that friction when it enacted subsection (d) in $1966 \ldots$...").

84. S. REP. No. 1797, 89th Cong., 2d Sess. 2, reprinted in 1966 U.S. CODE CoNG. \& ADMIN. NEwS 3663, 3664-65.

85. 28 U.S.C. $\$ 2254$ (d) (1982). Exceptions to the presumption are:

(1) that the merits of the factual dispute were not resolved in the State court hearing;

(2) that the factfinding procedure employed by the State court was not adequate to afford a full and fair hearing;

(3) that the material facts were not adequately developed at the State court hearing;

(4) that the State court lacked jurisdiction of the subject matter or over the person of the applicant in the State court proceeding;

(5) that the applicant was an indigent and the State court, in deprivation of his constitutional right, failed to appoint counsel to represent him in the State court proceeding;

(6) that the applicant did not receive a full, fair, and adequate hearing in the State court proceeding; or

(7) that the applicant was otherwise denied due process of law in the State court proceeding;

(8) or unless that part of the record of the State court proceeding in which the determination of such factual issue was made, pertinent to a determination of the sufficiency of the evidence to support such factual determination, is produced as provided for hereinafter, 
The general rule is that the phrase "issues of fact" refers to "what are termed basic, primary, or historical facts: facts "in the sense of a recital of external events and the credibility of their narrators." "86 When the result in a case turns on a factual finding that clearly requires the apphication of standards of law, the presumption of correctness normally given to findings of fact does not apply. ${ }^{87}$

Sumner v. Mata, ${ }^{88}$ the landmark case in the area of habeas review of state court factfinding, involved the distinction between factual and legal issues in the area of pretrial identification procedures. ${ }^{89}$ This decision illustrates the confusion surrounding the Supreme Court's interpretation of section 2254(d). The Supreme Court initially ruled that the United States Court of Appeals for the Ninth Circuit had failed to properly afford the presumption of correctness to the state court factfinding..$^{90}$ On remand, the court of appeals contended that because its disagreement with the state court involved the constitutional significance of certain facts, section 2254(d) was inapplicable..$^{11}$ On a second grant of certiorari, the Supreme Court held that although the ultimate constitutional question was a "mixed question of fact and law that is not governed by $\S 2254(d)$," all underlying factual findings had to be accorded the presumption of correctness. ${ }^{92}$ The Court vacated and remanded the case because some of the court of appeals' findings differed from those of the

and the Federal court on a consideration of such part of the record as a whole concludes

that such factual determination is not fairly supported by the record ....

28 U.S.C. $\$ 2254$ (d) (1982).

86. Townsend v. Sain, 372 U.S. 293, 309 n.6 (1963) (quoting Brown v. Allen, 344 U.S. 443, 506 (1953) (Frankfurter, J.) (separate opinion on the bearing of state court proceedings on application for writ of habeas corpus in a federal district court)); see also Cuyler v. Sullivan, 446 U.S. 335, 34142 (1980) (whether counsel undertook multiple representations is mixed question not entitled to presumption of correctness under section 2254(d)).

87. See Pullman Standard v. Swint, 456 U.S. 273, 286 n.16 (1982).

88. Sumner v. Mata, 449 U.S. 539 (1981) [hereinafter Mata I]; Sumner v. Mata, 455 U.S. 591 (1982) (per curiam) [hereinafter Mata $I I$ ].

89. Mata II, 455 U.S. at 597.

90. Mata I, 449 U.S. at 547. The Court ordered the court of appeals to either apply the presumption of correctness or set forth the reasons why it was led to conclude that the finding was "not fairly supported by the record." Id. at 551. Justice Brennan argued in dissent:

It is cruelly ironic that the Court would hold the constitutionality of pretrial identification procedures to be a question of law when the effect is to vacate a decision in favor of a prisoner . . . but would reject the same conclusion when the effect would be to vindicate such a prisoner's constitutional rights.

Id. at 558 .

91. The court of appeals concluded that section 2254(d) did not apply because the disagreement with the state court was "over the legal and constitutional significance of certain facts." Mata v. Sumner, 649 F.2d 713, 716 (9th Cir. 1981). The court found that whether a pretrial photographic identification procedure was impermissibly suggestive was a mixed question not entitled to the presumption of correctness. Id. at 717.

92. Mata II, 455 U.S. at 597. The Supreme Court asserted that the court of appeals must have "misunderstood [the] remand." Id. at 596-97. 
state court.93

Wilson presents an example of the problems with the Supreme Court's application of section 2254(d). The Supreme Court held in Wilson that the court of appeals failed to pay proper deference to the trial court's findings of fact. ${ }^{94}$ The Court failed, however, to recognize that deliberate elicitation is a mixed question of fact and law. ${ }^{95}$ Whetner de-

93. Id. at 598 .

94. 106 S. Ct. 2616, 2630 (1986).

95. Since the Mata decisions, the Court has further blurred the distinction between law and fact, reaching confusing results. For example, in Marshall v. Lonberger, 459 U.S. 422 (1983), the voluntariness of a guilty plea was at issue. The Court held that the court of appeals, which found the plea to be involuntary, failed to apply the presumption of correctness to the state court findings. Id. at 430-33. The Court noted that the federal court of appeals had described its own holding as " "directly contrary to the conclusions of both the Ohio courts that considered the question." "Id. at 431 (quoting Lonberger v. Jago, 651 F.2d 442, 449 (6th Cir. 1981)).

In Marshall, the issue in the petition for habeas corpus was whether the defendant's guilty plea was voluntary. Id. at 428 . The defendant testified at trial that he did not have knowledge of all the charges against him when he pleaded guilty. Id. at 433 (citing Lonberger, 651 F.2d at 449-50). The Court held that the trial court necessarily could not have believed the defendant; had the "trial court credited respondent's insistence that he had only been advised of or been aware of the battery charge," the court would have disallowed the admission of a previous attempted murder conviction. Id. at 433-34. But as the dissent pointed out, even if the defendant knew he was "charged with attempted murder, it does not necessarily follow that he knew he was pleading guilty to attempted murder." Id. at 443 (Brennan, J., dissenting). Thus, the findings of fact by the state court simply failed to resolve the case.

Rhetoric similar to that used by the Court in Marshall appears in other opinions overturning appellate decisions. In each case the Supreme Court pointed out that the court of appeals had reached a different result from all the other courts that considered the question. In Rushen v. Spain, 464 U.S. 114, 120 (1983), the Court held that a state court's ruling regarding a juror's impartiality is no different from any other factual determination for the purpose of applying section 2254(d). The dissent argued that the determination of this question was tantamount to determination of the federal question of constitutional error. Id. at $142 \mathrm{n} .22$ (Marshall, J., dissenting). Despite the fact that juror impartiality is a "complex and important federal question," the majority vacated the appellate court decision without the benefit of briefing by the parties. Id.

Following Rushen, the Court, in Patton v. Yount, 467 U.S. 1025 (1984), held that whether a juror could be impartial in the face of pretrial publicity was not a mixed question of law and fact, but one of simple historical fact: did the juror swear that he could ignore any opinion he held, and was his protestation of impartiality credible. Id. at 1036. While admitting that both factual and legal findings determine whether a juror is qualified, $i d$. at $1037 \mathrm{n} .12$, the Court insisted that a determination of juror impartiality is entitled to a presumption of correctness, $i d$. at 1038. Again the dissent is convincing: Justice Stevens argued that while a witness's truthfulness is a question of fact, whether his statement raises a presumption of partiality is a mixed question of fact and law. Id. at 1050 n.6 (Stevens, J., dissenting) (citing Reynolds v. United States, 98 U.S. 145, 156-57 (1879)).

The fact that legal determinations are at odds with the lower courts should be irrelevant. The Supreme Court should not be concerned with the ultimate conclusions reached by the lower courts; the appellate court should defer only to the factual determinations of the lower courts.

Commentators have expressed confusion and dismay over the Court's application of section 2254(d). See, e.g., Nichol, Backing into the Future: The Burger Court and the Federal Forum, $30 \mathrm{U}$. KAN. L. REV. 341, 357-59 (1982) (The Supreme Court's application of section 2254(d) has limited federal courts' inquiries into the accuracy and constitutional significance of state courts' factual determinations.); Pagano, Federal Habeas Corpus for State Prisoners: Present and Future, 49 ALB. L. REV. 1, 28-30 (1984) (The Supreme Court's broad interpretation of section 2254(d) may abridge the 
liberate elicitation occurred depends on the activities of the government and its agent. Their conduct is clearly a question of fact, while the constitutional and legal significance of that conduct should be viewed as a question of law. The state court found that Lee did not ask any questions of Wilson and that his statements were spontaneous and unsolicited.96 -Accepting this, the court of appeals found that deliberate elicitation had occurred under the standards of Henry and Massiah. ${ }^{97}$ The appellate court did not disregard the factfinding of the state court, but merely characterized the facts differently, drawing different legal conclusions. ${ }^{98}$ Because "deliberate elicitation" should be characterized as a mixed question of law and fact, the Court should not have applied section 2254(d)'s presumption of correctness.

\section{Secondary Considerations in Habeas Corpus Review.}

Legitimate but misplaced considerations may have colored the Supreme Court's application of section 2254(d). The Court has demonstrated an interest in finality ${ }^{99}$ and a reluctance to overturn a state court

power of federal courts to review state court convictions.); Reynolds, Sumner v. Mata: Twilight's Last Gleaming for Federal Habeas Corpus Review of State Court Convictions? Speculations on the Future of the Great Writ, 4 U. ARK. LiTTLE Rock L.J. 289, 291-92, 296, 298 (1981) (The Supreme Court's hostility toward the writ of habeas corpus demonstrated by its use of procedural mechanisms like section 2254(d) may destroy the writ's vitality for testing constitutionality of state court convictions.).

The Supreme Court's approach to section 2254(d) has also confused the courts of appeals. Since the Mata decisions, courts have treated many issues as legal that the Supreme Court might now characterize as factual. See, e.g., Smith v. Perini, 723 F.2d 478 (6th Cir. 1983) (Whether identification violated due process is a legal question entitled to full review.), cert. denied, 466 U.S. 941 (1984); United States ex rel. Caruso v. Zelinsky, 689 F.2d 435, 444 \& n.6 (3d Cir. 1982) (Whether defendant established in habeas corpus petition sufficient evidence that the state had offered him a plea bargain is a legal question.); United States ex rel. Scarpelli v. George, 687 F.2d 1012, 1015 (7th Cir. 1982) (Whether sixth amendment right of confrontation was violated is a mixed question not governed by the presumption of correstness.); Dickerson v. Alabama, 667 F.2d 1364, 1368-69 (11th Cir.) (Whether statements were sufficiently definite to constitute a request for a continuance is at least a mixed question and not entitled to presumption of correctness.), cert. denied, 459 U.S. 878 (1982); Panzavecchia v. Wainwright, 658 F.2d 337, 339 n.2 (5th Cir. 1981) (1ssue of prejudice is at least a mixed question and is not entitled to presumption of correctness.).

96. Wilson, $106 \mathrm{~S}$. Ct. at 2620.

97. Wilson v. Henderson, 742 F.2d 741, 744-45 (2d Cir. 1984). See supra notes $46-48$ and accompanying text. The court noted that prior decisions in the case had been rendered before Henry was decided. 742 F.2d at 747.

98. Justice Brennan's dissent in Mata II addressed a similar situation. He argued that there was no reason for disbelieving the court of appeals' insistence that it had accepted the factual findings of the state court. That court had simply disagreed with " "the legal and constitutional signifcance of certain facts. " Mata II, 45.5 U.S. at 600 (Brennan, J., dissenting) (quoting 649 F.2d 713, 716 (Ninth Circuit's opinion on remand from Mata I)).

99. In Mata I, the Court discussed the issue of finality as a footnote to its analysis of the fact/ law distinction: Section 2254(d) ensures that for the benefit of both the individual criminal defend- 
conviction of an "actually guilty" defendant. ${ }^{100}$ These concerns may have affected its assessment of the distinction between fact and law.

A determination that the critical issue in a case such as Wilson is a factual one reduces the chances that a habeas applicant will prevail. The federal courts may be powerless to review state court convictions. Curiously, this approach leaves the final constitutional determination in the hands of the state court. In a jailhouse informant case, if a state court finds that a confession is voluntary and not deliberately elicited, a federal court cannot find a constitutional violation unless it decides that the state court's factual determinations are not "fairly supported by the record."101 The federal court is stripped of its power to interpret the legal significance of facts. Whenever the state court in a jailhouse informant case says the magic words, that is, that the defendant's statements were "unsolicited" or "spontaneous," the federal court will be compelled to agree that there has been no constitutional violation.

The Supreme Court's disposition of Wilson was not compelled by any indisputable meaning of the word "fact." A malleable word such as "fact" does not control the judicial process. "Fact" will mean what the Court says it ineans whenever the definition persuades a niajority of the

ant and society "there will at some point be the certainty that comes with an end to litigation." 449 U.S. at 550 n.3; see also Engle v. Isaac, 456 U.S. 107, 126-27 (1982).

100. See, e.g., Wilson, $106 \mathrm{~S}$. Ct. at 2627 (Federal courts should entertain habeas petitions "only where the prisoner supplements his constitutional claim with a colorable showing of factual innocence."); Engle v. Isaac, 456 U.S. 107, 126-27 \& n.31 (1982) (" "[T] he proverbial man from Mars would surely think we must consider our system of criminal justice terribly bad if we are willing to tolerate such efforts at undoing judgments of conviction.' " (quoting Friendly, Is Innocence Irrelevant? Collateral Attack on Criminal Judgments, 38 U. CHI. L. REv. 142, 145 (1970))). In Stone v. Powell, 428 U.S. 465 (1976), the Court ruled that federal habeas review would be unavailable to state prisoners who claimed fourth amendment search and seizure violations unless the defendant could show that the state failed to provide "an opportunity for full and fair litigation." Id. at 494 . The Court found the prisoner's constitutional rights to be outweighed by other costs to society, such as diversion at trial from the "ultimate question of guilt or innocence" and exclusion of probative and reliable evidence. Id. at 489-90. The Court added that a convicted defendant making this claim was "usually asking society to redetermine an issue that ha[d] no bearing on the basic justice of his incarceration." Id. at 492 n.31.

Much has been written on the Supreme Court's strong interest in finality and actual guilt. See, e.g., Boyte, Federal Habeas Corpus After Stone v. Powell: A Remedy Only for the Arguably Innocent?, 11 U. RICH. L. REV. 291, 325-29 (1977) (Imposing a threshold of innocence for federal habeas corpus relief would subordinate due process values to interests in finality and guilt determination.); Guttenberg, Federal Habeas Corpus, Constitutional Rights, and Procedural Forfeitures: The Delicate Balance, 12 Hofstra L. REv. 617 (1984) (Neither Congress nor society supports the Supreme Court's preference for finality over certainty that a conviction is just.); Note, The Burger Court Limits of Habeas Corpus Review: Which Path to Follow-Procedural Hurdles or Fundamental Fairness?, 20 Hous. L. REV. 1417, 1419 (1983) (Recent decisions highlight the Supreme Court's emphasis on finality of judgment and conviction of the guilty.).

101. 28 U.S.C. $\$ 2254(\mathrm{~d})(8)$ (1982) (factual determinations presumed to be correct unless not fairly supported by the record). This note assumes none of the other exceptions to section 2254(d) apply. See supra note 85 for the text of the exceptions. 
justices. But such a meaning must be ascertained within a specific historical and political context. The merits of a litigant's contention, or the substantive issues at stake, color any interpretation; the Justices cannot operate in a vacuum or discount the beliefs that comprise the machinery of their minds. Goals, values, and prejudices will determine what "fact" means; the text is without the armament to fight back. ${ }^{102}$

If the Court has finality and actual guilt in mind when assessing the fact/law issue, it seems possible that such concerns would infect the thought processes of the Justices. This is not to imply that the Supreme Court is deliberately misconstruing the fact/law distinction; it merely suggests that other concerns may affect how the Court draws the fine line between questions of fact and law. ${ }^{103}$ When, as in Wilson, it is difficult rationally to justify a decision by looking solely at the analysis presented in the case, one must look elsewhere. ${ }^{104}$

102. See generally Fish, Working on the Chain Gang: Interpretation in the Law and in Literary Criticism, in The Politics of INTERPRETATION 271, 281 (W. Mitchell ed. 1983) (Interpretation is not constrained by "what is obviously and unproblematically 'there,' nor [is it] the case that interpreters ... are free to read into a text whatever they like .... Interpreters are constrained by their tacit awareness of ... what will and will not be heard as evidence in a given enterprise.").

103. This is also not to suggest that after considering the political consequences of a choice, the Justices choose one interpretation of "fact" over another; the point is that the Justices as interpreters can perceive the text only from the historical, judicial and political context that imprisons them. See generally Gordon, New Developments in Legal Theory, in THE Politics of LAW 281, 289 (1982) (belief structures are historically contingent); Michaels, Is There a Politics of Interpretation?, in THE Politics OF INTERPRETATION 335, 344 (W. Mitchell ed. 1983) ("[T] he whole project of conceiving interpretations as chosen is incoherent ....").

104. In Wilson, four Justices found that Wilson's second habeas petition should not have been heard because he had not made a colorable showing of innocence. Justice Powell, joined by Chief Justice Burger and Justices Rehnquist and O'Connor, argued that under section 2244(b), the statute governing successive review of state prisoners' claims, federal courts should entertain new habeas petitions for cases which have previously been heard by federal courts only "where the prisoner supplements his constitutional claim with a colorable showing of factual innocence." Wilson, $106 \mathrm{~S}$. Ct. at 2627. The defendant cannot make a colorable showing of innocence by demonstrating that he might not have been convicted had the unconstitutional evidence not been admitted. Id. at 2627 n.17. Instead he must show that in light of all the evidence, including the evidence in question, the trier of fact would have entertained a reasonable doubt as to his guilt. Id. This approach, Justice Powell argued, serves the important goal of finality that Congress had in mind when it enacted the 1966 amendments to section 2244. Id. at 2626.

Not surprisingly, the four Justices who would have denied the second habeas petition comprised part of the majority of six that held that the court of appeals failed to pay proper deference to the state court findings of fact. Id. at 2630-31. The result of both approaches advocated by these four Justices would be that an "actually guilty" defendant would remain in prison and not further burden the federal courts with habeas petitions. If the Court were applying procedural statutes neutrally, divorced from political or social concerns, it would not necessarily follow that the Justices who sought to deny rehearing would be the same as those who insisted on blind reliance on the state court's findings. But in Wilson, the Justices who were inclined to use one procedural weapon to reach a given result found a different procedural weapon to justify the same result. The supposed advantage of procedural as opposed to substantive rules is that procedural rules can be applied "neutrally," divorced from the political issues inherent in the substantive elements of a case. The 


\section{Impact of the Supreme Court's Application of Section 2254(d).}

The Supreme Court's approach to section 2254(d) denigrates federal court supremacy. Under the principles of federalism articulated in section 2254(d), federal courts should not disturb a supportable factual finding of a state court. ${ }^{105}$ But when there is an issue of constitutional law, federalism does not impair the federal court's jurisdiction. As Justice Brennan remarked, "A federal court need not-indeed, must not-defer to the state court's interpretation of federal law."106 The Wilson and Mata line of decisions creates uncertainty as to the federal courts' power to inquire into legal issues; state courts are left with the final word on critical constitutional questions. As Justice Marshall wrote, "If federal courts are obliged to defer to state-court findings of this order, the capacity of the federal courts through habeas proceedings to remedy deprivations of constitutional rights in state criminal trials will be substantially undercut." 107 Section 2254(d) clearly was not intended to interfere so drastically with the power of the federal courts. ${ }^{108}$

Protecting criminal defendants from the kind of government intrusion encountered in Henry is vital to the criminal justice system. The sixth amendment guarantees a criminal defendant the "right to rely on counsel as the 'medium' between himself and the State."109 The sixth amendment, therefore, "imposes on the State an affirmative obligation to respect and preserve the accused's choice to seek [the assistance of counsel]." "110 This right is violated when the state secures incrimmating information from the defendant by knowingly circumventing his right to have counsel present im a confrontation between the defendant and a gov-

Supreme Court plurality's procedural maneuvers in Wilson suggest otherwise. As Ronald Dworkin has said, "The flight from substance must end in substance." Dworkin, The Forum of Principle, 56 N.Y.U. L. REV. 469, 516 (1981) (arguing against theories that judicial review avoids "trespassing on democracy"). See generally Gordon, supra note 103, at 284 (Procedural rules are not "a set of neutral techniques available to anyone who could seize control of its levers and pulleys.").

105. Mata I, 449 U.S. 539, 547 (1981) (Federalism interest in section 2254(d) "requires deference by federal courts to factual determinations of all state courts.").

106. Id. at 559 (Brennan, J., dissenting); see Note, Stone v. Powell and the New Federalism: $A$ Challenge to Congress, 14 HARV. J. ON LEG1S. 152, 168 (1976) ("In a federal system premised on the supremacy of federal law, some federal supervision of the state courts in their determination of federal constitutional claims is necessary.").

107. Rushen v. Spain, 464 U.S. 114, 142 n.22 (1983) (Marshall, J., dissenting). Rushen was decided after the Mata decisions and before Wilson. The majority held that the "substance of the exparte communications and their effect on juror impartiality are questions of historical fact. ... Thus, they must be determined, in the first instance, by state courts and deferred to, in the absence of 'convincing evidence' to the contrary, by the federal courts." Id. at 120.

108. See supra notes $79-84$ and accompanying text.

109. Kuhlmann v. Wilson, 106 S. Ct. 2616, 2637 (1986) (Brennan, J., dissenting) (quoting Maine v. Moulton, 474 U.S. 159, 176 (1985)).

110. Id. (quoting Moulton, 474 U.S. at 485). 
ernment agent. As the Court held in Henry, the government's use of a jailhouse informant robs the defendant of vital constitutional rights. While under the mental and physical strains of custody, he is housed with a fellow cellmate whose job it is to secure incriminating information from him. If the informant entices the defendant to confess, his actions should be regarded as a surreptitious form of interrogation.

The jailhouse informant situation is far more ripe for abuse than ordinary interrogation in a police station, and hence the defendant has an even greater need for protection. At the police station, the defendant at least knows he is being interrogated. In the jailhouse, however, the government is extracting a confession from the defendant that he does not expect to be used against him. The Supreine Court in Henry rightly sought to discourage this type of reprehensible police behavior. ${ }^{111}$ Precedent has established that the accused has a vital right to have counsel present at interrogations; ${ }^{112}$ this must continue to be read to include indirect and surreptitious interrogation as well as the more formal police interrogations. In Wilson, the Court did not protect the defendant's rights because the Court failed to recognize that dehberate elicitation is a legal conclusion subject to federal review.

\section{CONCLUSION}

The Supreme Court has long protected the sixth amendment right to counsel. In United States v. Henry, the Court sought to preserve those rights in the jailhouse inforniant context. Six years later, in Kuhlmann $v$. Wilson, the Court sent confusing signals to the lower courts concerning the vitality of those rights. Wilson on its face could be read as overturning or limiting Henry. But the Supreme Court relied on Henry and did not explicitly reverse it.

This note has argued that the two decisions can be reconciled by reading Henry as a decision about jailhouse informants and Wilson as a

111. United States v. Henry, 447 U.S. 264, 273-74 (1980). This police behavior appears particularly odious when one considers the relationship that the police exploit. To succeed at his job, an informant must gain the confidence of the criminal defendant; within the powerful confines of a prison environment, the informant must deceptively become the defendant's friend. Once the informant lulls his "friend" into a false sense of security, the defendant can speak candidly of his behavior. In the presence of his friend, the defendant feels as comfortable as he would if he were talking to himself. As Francis Bacon wrote, "a friend is another himself." Bacon, On Friendship, in The Great Thoughrs 28 (G. Seldes ed. 1985). Accepting this, one could argue that the police behavior condemned in Henry but permitted in Wilson comes dangerously close to violating the defendant's fifth amendment right against self-incrimination. Furthermore, confessions obtained through indirect and surreptitious interrogations not only interfere with the defendant's constitutional rights, but are also unreliable. An informant has a powerful incentive to lie or distort the truth, and his credibility is inherently suspect; he has nothing to lose.

112. See supra notes 3-10 and accompanying text. 
decision about the standards for habeas review of state court convictions. Thus, lower courts can both freely apply the standards of deliberate elicitation articulated in Henry and attempt to apply the standards of review articulated in Wilson. This note has also pointed out, however, that the Supreme Court's misapplication of 2254(d) to mixed questions of fact and law, such as deliberate elicitation, makes it difficult for lower courts to follow its demands. Furthermore, as a result of the Supreme Court's disposition of Henry and Wilson, federal courts are left with waning authority to overturn state court convictions when they perceive constitutional violations. The Supreme Court has relieved the federal courts of the burden of reviewing certain legal questions-and has also, perhaps, relieved them from the burden of achieving justice.

Louis D. Lappen 